\title{
Codes of Ethics and Their Place in Education
}

\author{
Miroslav Krč ${ }^{*}$
}

\begin{abstract}
The paper deals with the place of codes of ethics within the system of ethical work. In schools in Olomouc district, we analyzed whether they use codes of ethics and how they deal with them. In this region, there are 153 schools and the sample consisted of 80 schools. The research problem was set whether the teaching profession needs its own code of ethics. The advantages of a mandatory code of ethics or a generated code as their own initiative are analyzed here. The research results indicate that the best way is to provide schools a sample code of ethics and let them adapt it to their specific conditions. The research has been mixed, it includes a quantitative research that describes phenomena using variables and qualitative research interpreting the respondents' views on the relation of ethics and professional conduct. The greatest lack a code of ethics was found in secondary vocational schools. Secondary grammar schools usually treated ethical codes. In most European countries, it represents one of the curriculum options in ethical education.
\end{abstract}

Key words: ethics, code of ethics, education.

\section{Introduction}

Codes of ethics serve as a formalized ground for easier and more accurate assessment of behaviour. In addition, codes of ethics have an unmistakable, morally educative and preventive meaning. The teaching profession does not dispose of an officially established code of ethics, unlike physicians, social workers and others. Many schools have their own code. Most of them are private schools that have realised that as the pupils have their rights and duties towards the school, these rights and duties are required from teachers, too. Its creation is not a replacement or extension of the Conditions of Employment. Its main goal should lie in motivation of each teacher.

\footnotetext{
* Miroslav Krč, Dubnica Institute of Technology in Dubnica nad Váhom, Dubnica nad Váhom, Slovakia; krc@dti.sk
} 


\section{Acta Technologica Dubnicae \\ volume 5, 2015, issue 3}

Therefore, the question should be whether the teaching profession needs its own code of ethics. People with high emotional intelligence are perceptive and thanks to the ability they know how to make right decisions and act adequately. They do not need a code of ethics. Other people do not dispose by this talent and such a code could help them.

\section{Ethics and Codes of Ethics}

Ethics has served as the basis of the original law, but law contains a minimum of ethics. By means of ethics, one should be able to say whether what individuals or a companies do is good or bad. The answer is ambiguous due to individual and ethnic differences. Ethics is a normative science and defines the scope of ethical principles that are called codes of ethics. Codes of ethics represent only a morally binding norm, but they should not contradict the current legislation. Ethics by Sokol can be described as follows: "A science of morality is part of practical philosophy; it asks what is right and wrong and what should and should not be." (Sokol, 2010, p. 66).

Ethics by Nytrova is not to determine "what we may and what we must not, but it always helps us to seek and expand what is moral, what is indecent and that we can act correctly or incorrectly. Ethics is closely associated with the theory of values. As "good" is ethically considered as the supreme human value, ethics teaches to recognize what is good and what is not good." (Nytrova, 2007, p. 34). "A person acts morally if he/she behaves knowingly and willingly consistently with obligations, otherwise we can talk about immoral behavior." (Jankovsky, 2003, p. 223).

Morality determines socially desirable and undesirable conduct, and thus it influences human behavior in the society. We assume that humans are rational entities and that free and rational decision making is a necessary condition for moral responsibility. Ethics should look at what is right and what is wrong, what is good and what is evil; it should examine moral decisions of people and the ways in which they try to justify.

Codes of ethics define the standards of behavior in the workplace; their existence is evident in larger and multinational companies. At present, companies work out the basic ethical values, and they represent a key management tool. Currently, the Code of Ethics is one of the most common tools of implementation of ethical principles into business practice.

A Code of Ethics should identify certain desirable boundaries of behavior. A Code of Ethics serves for determining the principles and rules of behaviour and it is mostly based on the defined goal and values of specific company. Generally, 


\section{Acta Technologica Dubnicae \\ volume 5, 2015, issue 3}

codes of ethics are drawn up to define the relationships with the public, employers, customers and other professional groups. It depends on the particular organization and its specific focus, how its specifies its own ethical code, how it communicates it, whether the code is periodically revised, to what extent it is mandatory for the employees and whether its violation is penalized.

Many professional disciplines have developed codes of ethics that are more or less binding on the competent employees. In some areas, e.g. advocacy, medicine, forensic expertise, there are ethical codes with serious legal validity. In some professional associations, e.g. the Czech Educational Research Association, codes of ethics do not have legal consequences and their members can adopt them voluntarily.

The professional skills and values of the teaching profession require from teachers gathering a lot confidential information concerning the lives of students. Their steps must be in accordance with the ethical principles of the teaching profession. The definition the teaching profession should be based on the professional values and knowledge that can be summed up as follows:

- teachers should show their passion for their profession and for working with pupils (students);

- teachers reflect on their work, i.e. they are able to describe, analyze and evaluate it, to explain the reasons for their conduct or to propose alternative ways of working;

- teachers plan their future professional progress and their professional competence (attitudes and values, knowledge and skills of pedagogicalpsychological, industrial-educational, professional, labor law, knowledge and skills of modern information technology);

- teachers plan their professional progress in accordance with the objectives and tasks of school;

- teachers use a variety of means available, e.g. literature, internet, consulting with colleagues, education courses for teachers;

- teachers evaluate their teaching and educational progress continuously and they are able to demonstrate their career steps;

- teachers take care of their physical and mental health;

- teachers avoid actively stress and burnout.

In addition to professional knowledge and professional skills, we can find other factors defining the teaching profession, e.g. the key responsibilities of teachers in the educational process. Some authors accentuate the value dimension and ethical responsibility. Here, the professional values of teachers as more important than their knowledge and skills. 


\section{Acta Technologica Dubnicae \\ volume 5, 2015, issue 3}

Talking about ethics is not the same as doing ethics. Achieving a consensus is not doing ethics. An ethical solution is not necessarily what produces happiness or satisfaction of the interests of all those who are involved. Any decision made by an educator related to what the educator does as an educator contains an ethical component as education involves the interaction of human beings - the base and generation of ethical concern. Many of the decisions to be made involve a set of common ethical issues although they will be set within a wide array of circumstances.

There are some basic steps or phases that a person should go through in making decisions of a moral nature:

1 Identify the ethical issues involved in the situation and the decision to be made;

2 Consider a number of possible alternatives;

3 Consider the possible consequences for learners;

4 Identify the possible harms in each alternative;

- avoidable harms/unavoidable harms;

- necessary harms/ unnecessary harms;

5 Identify the benefit of each alternative.

\section{Codes of Ethics Analysis}

Developed professional values and professional skills are a prerequisite for creating a code of ethics. Codes of ethics have been developed by some secondary schools and universities. They include the competences of teachers, relationships within schools and between teachers. On the upper secondary level, they have already been on the rise, especially in private secondary schools and colleges. The share of ethical codes in secondary and higher education is over $50 \%$. To examine the current status regarding codes of ethics, we have analyzed schools in the Olomouc district. The total number of schools here is 153. (https://www.czso.cz/; https://vdb.czso.cz/vdbvo/tabparam.jsp?cislotab=VZD 4010UC\&kapitola_id=17\&voa=tabulka\&go_zobraz=1\&childsel0=3).

An electronic questionnaire was sent to 86 schools and 80 completed questionnaires were returned. The analysis was carried out using the returned questionnaires from different schools. This research can be classified as mixed as it involves a quantitative research that describes phenomena using variables and a qualitative research interpreting the respondents' views regarding the relation of ethics and economic behavior, especially by means of the last three questions in the questionnaire. What we found was that 41 schools had already created their own codes of ethics, 8 schools were to create it. The analysis showed that codes of ethics do not differ from school to school, though each school had formulated its own code of ethics. It can be stated that the existence 


\section{Acta Technologica Dubnicae \\ volume 5, 2015, issue 3}

of codes of ethics is gaining importance in education process. A code of ethics is missing most at secondary technical and vocational schools. Secondary grammar schools are an exception as they usually apply a code of ethics.

In 21 schools, own codes of ethics were worked out based on the school's own initiative and in 20 schools it was recommended by the founder. Ethical codes met their aim in 33 schools and only 8 schools did not think so. It is a positive finding that the schools did not just take over a ready code of ethics, but they tried to take into account the specifics and the orientation of the school. Approximately the same was in the case of the answer to the question whether the code of ethics was "mandatory for you" - respondents from 34 schools answered "yes", from 7 schools "no". More than 90\% of schools expressed that their code of ethics was sufficient. However, the respondents were dissatisfied with the fact that their code of ethics did not reflect the specialization of the school, was not related to the pupils, colleagues or the public, and did not reflect the professional orientation of the school.

Only $36 \%$ of the respondents called for the legitimization of the code of ethics. Conversely, 64\% expressed a negative opinion. The result gives us an answer to the question whether it is beneficial to legitimize the codes of ethics. The majority of teachers did not consider legitimization necessary. While $62 \%$ of respondents expressed that the legal anchoring of the code of ethics would not cause an increase in the quality of teachers, $38 \%$ of the respondents expressed the opposite opinion. $85 \%$ of respondents expressed the opinion that schools that had created a code of ethics where better at assessing pupils' behavior than those that had not created it.

The liability and the possibility of penalties for non-compliance of the code of ethics are quite high. Up to $80 \%$ of schools expressed that their code of ethics is on the level of the conditions of employment and there is the possibility of sanctions in case of its violation. Only for $10 \%$ of the respondent perceived the code of ethics as advisory but still respected. The results show that the respondents consider the code of ethics as something that to a big extent supports the quality of teachers, schools and education. 92\% of schools rated their code of ethics as sufficient. Only in three cases the respondents indicated certain drawbacks. These include that their code of ethics did not represent or respect the specialization of their school and did not include the relationship with students, their colleagues or the public. The majority (65\%) expressed disapproval when being asked whether they would welcome legal anchoring of the code of ethics in education.

Social responsibility is closely related to ethics, although ethical responsibility is not legitimized. However, ethical behavior and trust suffer largely under present 


\section{Acta Technologica Dubnicae \\ volume 5, 2015, issue 3}

circumstances, because of interest groups' clientism. In a research of the Transparency International of the Czech Republic in 2005, the attitudes of Czech managers towards ethical principles abiding were surveyed. The survey included 254 Czech managers from middle management and 50 top managers. 68\% respondents stated that the most important motive for responsible behavior were the ethical and moral reasons (Pavlik, 2010). This finding corresponds with the results of our research (2015) in the education sector, where $62 \%$ of respondents stated that the legitimization of a code of ethics did not automatically lead to ethical behavior.

\section{Pedagogical Competence and Ethics}

How is the relationship between competence and ethics manifested? When selecting applicants, their competence should be considered primarily. Competence is defined as a person's ability to behave in an appropriate manner to the requirements of the job and thus to contribute to the desired outcomes of a company. Professional ethics has an important role in an employee's competencies, it forces professionals to be more ethical; develops value orientation and moral thinking; and helps to understand properly the role and importance of professional positions in the contemporary society.

The notion of profession is understood as a specific term and it appears in relation to a specific group of professions based on long-term theoretical training. Professional competencies are considered to be the general ability to perform a job successfully, e.g. teaching vocational courses. Therefore, they create an essential prerequisite for a teacher's performance not only at this, but also at a future job position. Competencies are represented by skills and knowledge that are widely applicable.

According to Podlahova (2012), teaching skills necessary for the teaching profession, "are also known as didactic, they do not only consist of the ability to teach, give lectures or application of methods, principles and expertise in techniques of education. Teaching competencies mainly represents a set of specific and highly expert knowledge, skills, attitudes and experiences that are consistent with the educational process, reflect changes in the society, and take into account the intellectual predispositions, personality, individual interests and educational needs of students".

Professional competence represents an essential prerequisite for the teaching profession. It expresses knowledge, skills, abilities and attitudes of teachers they should achieve. To achieve these educational skills, teachers must become familiar with the basics of didactics and psychology, have life experience and skills of self-reflection. The most effective way of knowledge acquisition for 


\section{Acta Technologica Dubnicae \\ volume 5, 2015, issue 3}

building and fixing educational skills necessary for teachers at all levels of education is the study and mastery of the basic teaching methods.

Several associations have been created in the last 20 years, tending to solve the current status of education with the support of expert knowledge, professional competence and moral property, e.g. Teacher Profession Association, Friends of Engaged Learning, the Association of Directors of Elementary Schools, the Association of Teachers of Secondary Schools, etc. Nevertheless, none of these associations set a code of ethics in the narrow meaning. Their ethical codes replace the statutes of the association, goals and mission and they just serve to ensure the moral credit of each individual profession.

\section{Code of Ethics}

The National Education Association (1975) believes that the education profession consists of one education workforce serving the needs of all students and that the term 'educator' includes education support professionals. The educator, believing in the worth and dignity of each human being, recognizes the supreme importance of the pursuit of truth, devotion to excellence, and the nurture of the democratic principles. Essential to these goals is the protection of freedom to learn and to teach and the guarantee of equal educational opportunity for all. The educator accepts the responsibility to adhere to the highest ethical standards.

The educator recognizes the magnitude of the responsibility inherent in the teaching process. The desire for the respect and confidence of one's colleagues, of students, of parents, and of the members of the community provides the incentive to attain and maintain the highest possible degree of ethical conduct. The Code of Ethics of the Education Profession indicates the aspiration of all educators and provides standards by which to judge conduct.

The remedies specified by the NEA and/or its affiliates for the violation of any provision of this Code shall be exclusive and no such provision shall be enforceable in any form other than the one specifically designated by the NEA or its affiliates.

\section{Principle I}

\section{Commitment to the student}

The educator strives to help each student realize his or her potential as a worthy and effective member of society. The educator therefore works to stimulate the spirit of inquiry, the acquisition of knowledge and understanding, and the thoughtful formulation of worthy goals. In fulfilment of the obligation to the student, the educator: 


\section{Acta Technologica Dubnicae \\ volume 5, 2015, issue 3}

1. Shall not unreasonably restrain the student from independent action in the pursuit of learning.

2. Shall not unreasonably deny the student's access to varying points of view.

3. Shall not deliberately suppress or distort subject matter relevant to the student's progress.

4. Shall make reasonable effort to protect the student from conditions harmful to learning or to health and safety.

5. Shall not intentionally expose the student to embarrassment or disparagement.

6. Shall not on the basis of race, color, creed, sex, national origin, marital status, political or religious beliefs, family, social or cultural background, or sexual orientation, unfairly:

a. Exclude any student from participation in any program.

b. Deny benefits to any student.

c. Grant any advantage to any student.

7. Shall not use professional relationships with students for private advantage.

8. Shall not disclose information about students obtained in the course of professional service unless disclosure serves a compelling professional purpose or is required by law.

\section{Principle II}

\section{Commitment to the profession}

The education profession is vested by the public with a trust and responsibility requiring the highest ideals of professional service.

In the belief that the quality of the services of the education profession directly influences the nation and its citizens, the educator shall exert every effort to raise professional standards, to promote a climate that encourages the exercise of professional judgment, to achieve conditions that attract people worthy of the trust to careers in education, and to assist in preventing the practice of the profession by unqualified persons.

In fulfillment of the obligation to the profession, the educator:

1. Shall not in an application for a professional position deliberately make a false statement or fail to disclose a material fact related to competency and qualifications.

2. Shall not misrepresent his/her professional qualifications.

3. Shall not assist any entry into the profession of a person known to be unqualified in respect to character, education, or other relevant attribute.

4. Shall not knowingly make a false statement concerning the qualifications of a candidate for a professional position.

5. Shall not assist a non-educator in the unauthorized practice of teaching. 


\section{Acta Technologica Dubnicae \\ volume 5, 2015, issue 3}

6. Shall not disclose information about colleagues obtained in the course of professional service unless disclosure serves a compelling professional purpose or is required by law.

7. Shall not knowingly make false or malicious statements about a colleague.

8. Shall not accept any gratuity, gift, or favor that might impair or appear to influence professional decisions or action.

\section{Conclusion}

Codes of ethics have been formulated by one half of all the schools in the Olomouc district. The codes of ethics are parts of the internal directive or organizational rules. The codes of ethics have been created on the basis of the schools' own initiative or the founder's recommendation. The specifics of each school are respected in the code of ethics by $80 \%$ schools of the total number. Only $10 \%$ of schools expressed the view that the code of ethics of their school is too general and does not respect the school's specifics. More than two thirds of the ethical codes support a proactive approach to protecting the environment and take into account the economic priorities. The code of ethics is specified according the orientation of a particular school.

Not only in education is the behavior of employees controlled by certain rules. Some assignments or directives may have the form of recommendations that are traditionally observed. Some must be signed and affirmed to be respected and their violation will be penalized up to dismissing an employee.

In general, principles related to teachers' treatment of students, educational process, preserving and enhancing the dignity of the staff are considered as the foundations of pedagogic ethics. And if they are additionally regulated by a code of ethics in accordance with the specific orientation of the school, their significance and prestige are increased even more.

However, legitimization of a code of ethics does not increase the quality of teachers, but creating their own code of ethics in accordance with the specific orientation of the school, would affect the behavior of teachers towards pupils (students). This fact has also been observed throughout this research. Teachers prefer codes of ethics created by their own school to legitimizing it. It seems to be appropriate to follow the basic points of the general code of ethics which should be modified according to the specifics, technical orientation and other aspects of a particular school. 


\section{Acta Technologica Dubnicae \\ volume 5, 2015, issue 3}

\section{References}

Dytrt, Z. (2006). Etika v podnikatelském prostředí. Praha: Grada.

Havlík, R., \& Kot’a, J. (2007). Sociologie výchovy a školy. Praha: Portál.

Jankovský, J. (2003). Etika pro pomáhajicí profese. Praha: Triton.

Nytrová, O., \& Pikálková, M. (2007). Etika a logika v komunikaci. Praha: Univerzita Jana Amose Komenského Praha.

Pavlík, M., \& Bělčík, M. (2010). Společenská odpovědnosti organizace: CSR v praxi a jak s ním dál. Praha: Grada.

Podlahová, L. (2012). Didaktika pro vysokoškolské učitele. Praha: Grada.

Putnová, A. (2007). Etické ř́zeni ve firmè, nástroje a metody, etický a sociální audit. Praha: Grada.

Remišová, A. (2011). Etika a ekonomika ( ${ }^{\text {rd }}$ revised ed.). Bratislava: Kalligram.

Sokol, J. (2010). Etika a život: pokus o praktickou filosofii. Praha: Vyšehrad.

Telec, I. (2010, March 22). Etické kodexy vysokých škol. Retrieved from http://jinepravo.blogspot.cz/2010/03/ivo-telec-eticke-kodexy-vysokychskol.html

Univerzita Palackého v Olomouci (2008). Etický kodex akademických a odborných pracovniku. Retrieved from http://www.upol.cz/skupiny/zamestnancum/predpisy-formulare/

National Education Association. (n.d.) Code of Ethics. Retrieved from http://www.nea.org/home/30442.htm

Český statistický úrad. (n.d.) Retrieved from https://vdb.czso.cz/vdbvo/ tabparam.jsp?cislotab=VZD4010UC\&kapitola_id=17\&voa=tabulka\&go_zo braz $=1 \&$ childse $10=3$

The National Education Association. (1975). Retrieved from http://www.nea.org/home/30442.htm 